\title{
Confocal Analysis of Reciprocal Feedback at Rod Bipolar Terminals in the Rabbit Retina
}

\author{
Jian Zhang, Wei Li, E. Brady Trexler, and Stephen C. Massey \\ Department of Ophthalmology and Visual Science, University of Texas-Houston Medical School, Houston, Texas 77030
}

Amacrine cells in the mammalian retina are famously diverse in shape and function. Here, we show that two wide-field GABA amacrine cells, S1 and S2, have stereotyped synaptic contacts with the appropriate morphology and distribution to perform specific functions. S1 and S2 both supply negative feedback to rod bipolar terminals and thus provide a substrate for lateral inhibition in the rod pathway. Synapses are specialized structures, and the presynaptic compartment is normally characterized by a swelling or varicosity. Each $\mathrm{S1}$ amacrine cell has $\sim 280$ varicosities, whereas an S2 cell has even more, $\sim 500$ per cell. Confocal analysis shows that essentially all varicosities aggregate around rod bipolar terminals where they are apposed by postsynaptic GABA receptors. Each rod bipolar terminal is contacted by varicosities from $\sim 25$ different S1 and 50 different S2 amacrine cells. In fact, rod bipolar cells are the only synaptic target for S1 and S2 amacrine cells: all of the output from these two wide-field GABA amacrine cells goes to rod bipolar terminals. It has long been a puzzle why two amacrine cells, apparently with the same connections, are required. However, an analysis of the distribution of varicosities suggests that $\mathrm{S} 1$ and S2 amacrine cells provide different signals. S2 amacrine cells dominate within $200 \mu$ from a rod bipolar terminal and can provide an inhibitory input with spatial characteristics that match the size of the surround signal recorded from All amacrine cells in the rod pathway. In contrast, the larger, bettercoupled S1 amacrine cells may provide a more distant network signal.

Key words: retina; S1 amacrine cell; S2 amacrine cell; rod bipolar cell; All amacrine cell; confocal microscopy; Neurobiotin
There are multiple rod and cone pathways through the mammalian retina (for review, see Sterling, 1998; Bloomfield and Dacheux, 2001). Cones diverge to multiple types of ON and OFF cone bipolar cells, which synapse directly with ganglion cells. In contrast, many rods converge onto a single morphological type of rod bipolar cell (RBC), which makes excitatory dyad synapses predominantly with two postsynaptic amacrine cells (Strettoi et al., 1990). Synapses with one amacrine cell, the AII, are conventional. In turn, the AII makes gap junctions with ON cone bipolar cells and glycinergic synapses with OFF cone bipolar cells (Strettoi et al., 1992). Alternative rod pathways via rod-cone coupling or direct connections between rods and OFF cone bipolar cells have also been reported (DeVries and Baylor, 1995; Soucy et al., 1998).

The other postsynaptic element at each rod bipolar dyad makes a reciprocal synapse and is derived from one of two wide-field GABA amacrine cells known as S1 and S2 (Sandell and Masland, 1986; Vaney, 1986; Strettoi et al., 1990). Although there is not

\footnotetext{
Received July 31, 2002; revised Oct. 1, 2002; accepted Oct. 2, 2002.

This work was supported by National Eye Institute Grant EY06515, Vision Core Grant EY10608, Vision Training Grant EY07024 (E.B.T.), and an unrestricted grant from Research to Prevent Blindness to the Department of Ophthalmology and Visual Science. S.C.M. is a Hanse-Wissenschaftskolleg Fellow (Delmenhorst, Germany) and the grateful recipient of a sabbatical award from Research to Prevent Blindness. We thank Dr. Stephen Mills for stimulating discussions, Dr. Alice Chuang and Andrzej Zych for programming and data analysis, and Sunny Liu for technical assistance.

Correspondence should be addressed to Dr. Stephen C. Massey, Department of Ophthalmology and Visual Science, University of Texas-Houston Medical School, 6431 Fannin Street, MSB 7.024, Houston, TX 77030. E-mail: steve.massey@ uth.tmc.edu.

Dr. J. Zhang's present address: Department of Ophthalmology, Baylor College of Medicine, 6565 Fannin Street, NC-205, Houston, TX 77030.

Copyright @ 2002 Society for Neuroscience $\quad 0270-6474 / 02 / 2210871-12 \$ 15.00 / 0$
}

much endogenous serotonin in the rabbit retina, these cells accumulate serotonin, which provides a simple way to label the mosaic of S1 and S2 amacrine cells. Both $\mathrm{GABA}_{\mathrm{A}}$ and $\mathrm{GABA}_{\mathrm{C}}$ receptors have been localized to the rod bipolar terminal at a proportion of S1 and S2 contacts (Fletcher and Wässle, 1999), and GABA-mediated negative feedback seems to be a common feature of bipolar cell terminals (Marc and Liu, 2000).

The S1 is a wide-field amacrine cell with straight radiating dendrites decorated with large varicosities (Sandell and Masland, 1986; Vaney, 1986). The S2 is smaller, and the dendrites are more tangled and bear smaller varicosities. Both cell types contribute to a dense overlapping plexus at the level of rod bipolar terminals. Recordings show that rabbit S1 amacrine cells have depolarizing responses and produce spikes (Bloomfield, 1996). Furthermore, AII amacrine cells in the rod pathway have an inhibitory surround that is mediated by GABA and blocked by tetrodotoxin, which led to the suggestion that S1 cells contribute surround signals to the rod pathway via feedback to the rod bipolar terminal (Bloomfield and Xin, 2000).

There are several outstanding questions concerning the role of S1/S2 amacrine cells. First, are there contacts with other bipolar cells besides rod bipolar cells? Second, why is there an apparent mismatch in the small size of the AII surround $(\sim 100 \mu \mathrm{m})$ and the large extent of the $\mathrm{S} 1$ dendritic field $(>1 \mathrm{~mm})$. Third, why is it necessary to have two closely related amacrine cell types with apparently identical connections to do the same job? In this paper, we have used confocal microscopy to analyze S1 and S2 amacrine cells in detail. We find that $\mathrm{S} 1$ and $\mathrm{S} 2$ varicosities are synaptic sites, apposed by GABA receptors and always in contact with rod bipolar cells. We have also modeled the distribution of S1 and S2 amacrine cells contacting a single rod bipolar cell. 
Figure 1. Triple-label imaging of rod bipolar contacts with the S1/S2 matrix and AII amacrine cells. $A$, The $\mathrm{S} 1 / \mathrm{S} 2$ matrix, focus in sublamina 5 , labeled with an antibody to serotonin after preloading. The matrix consists of many overlapping fine dendrites with clusters of varicosities (an example indicated by the arrow). Large holes in the matrix are protruding ganglion cells or Müller cells passing through. $B$, Double-label image, same field, shows that rod bipolar terminals, labeled with anti-PKC (blue), fill small holes in the S1/S2 matrix and are surrounded by several varicosities (same arrow as in $A$.). $C$, The matrix of AII dendrites (same field), labeled with anti-calretinin (red), is less dense than the S1/S2 matrix, but every rod bipolar terminal (blue) contacts an AII process. $D$, Triple-label image showing rod bipolar terminals (blue), inserted in the combined S1/S2 matrix and AII matrix (red). There is almost no overlap among the three labels: they stain separate neuronal types. Individual rod bipolar terminals (blue) are often enclosed completely by alternating S1/S2 contacts or AII contacts (red).
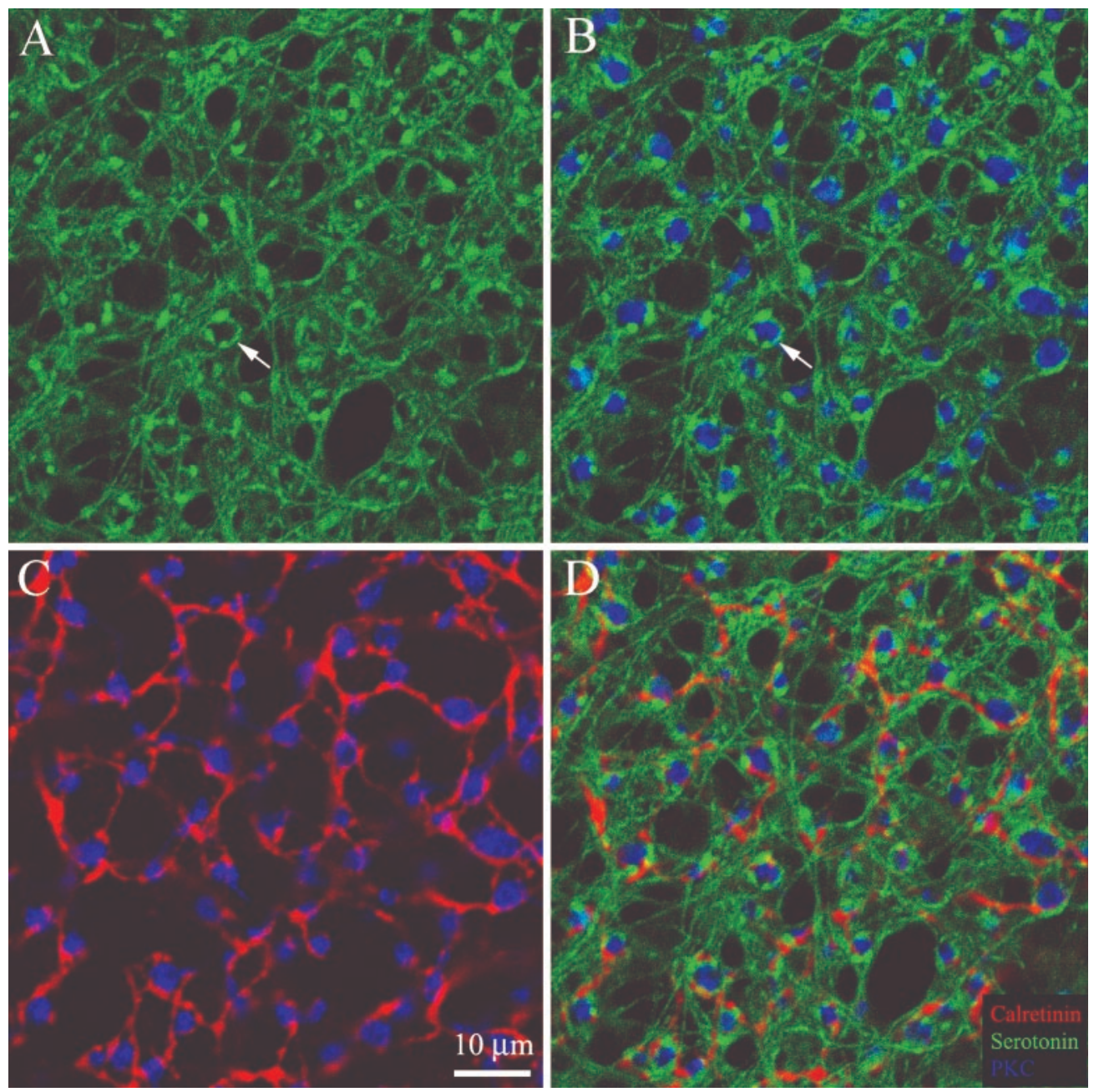

These calculations suggest that nearby surround inputs are dominated by $\mathrm{S} 2$, whereas $\mathrm{S} 1$ has relatively few and distant contacts.

\section{MATERIALS AND METHODS}

Preparation. The isolation of rabbit retina has been described previously (Massey and Mills, 1996). In brief, adult New Zealand Albino rabbits of either sex were anesthetized with urethane (loading dose, $1.5 \mathrm{gm} / \mathrm{kg}$, i.p.), and the orbit was infused with $2 \%$ lidocaine hydrochloride before enucleation. The eyes were removed and hemisected, and the retina was isolated from the inverted eye cup while immersed in oxygenated Ames medium (Ames and Nesbett, 1981). The isolated retina was flattened onto filter paper, photoreceptor down, and incubated in fresh Ames medium containing $10 \mu \mathrm{M}$ serotonin (5-hydroxytryptamine; Sigma, St. Louis, MO) for $30 \mathrm{~min}$. Then, the preparation was fixed for 30-60 min with $4 \%$ formaldehyde in phosphate buffer. Alternatively, for intracellular dye injection, pieces of isolated retina were submersed with $5 \mu \mathrm{M}$ 6-diamino-2-pheylindole (DAPI) together with $10 \mu \mathrm{M}$ serotonin for 30 min to prelabel amacrine cell nuclei in the inner nuclear layer (INL). S1 and $\mathrm{S} 2$ cells could be identified by their large and lightly stained somas.

Antibodies. A rabbit or goat polyclonal antibody to calretinin (Chemicon, Temecula, CA) was used at a dilution of 1:10,000. A rabbit polyclonal (Chemicon) or mouse monoclonal antibody (Transduction Laboratories, San Diego, CA) against protein kinase C (PKC) was diluted at 1:1000. A goat polyclonal antibody against serotonin (Incstar, Stillwater, $\mathrm{MN}$ ) was diluted at 1:1000. An antibody against synaptophysin (Sigma) was diluted at 1:500. Antibody to the $\mathrm{GABA}_{\mathrm{C}}$ receptor was a generous gift from Dr. Heinz Wässle (Department of Neuroanatomy, Max Planck Institute for Brain Research, Frankfurt am Main, Germany) (1:100) (Enz et al., 1996). The monoclonal antibody to synaptic vesicle 2 (SV2) (1:1000), developed by Dr. Kathleen Buckley (Department of Neurobiology, Harvard Medical School, Boston, MA), was obtained from the
Developmental Studies Hybridoma Bank developed under the auspices of the National Institute of Child Health and Development and maintained by the Department of Biological Sciences, University of Iowa. Secondary antibodies were obtained from Jackson ImmunoResearch (West Grove, PA) and used at a dilution of 1:200.

Intracellular dye injection. S1 and S2 amacrine cells were impaled under visual control with sharp electrodes. Electrode tips were filled with a mixture of $1 \%$ Lucifer yellow-CH and $4 \%$ Neurobiotin (Vector Laboratories, Burlingame, $\mathrm{CA}$ ) in $50 \% 0.05 \mathrm{M}$ phosphate buffer $(\mathrm{PB})$, and then back-filled with 3 м lithium chloride. After penetration, Lucifer yellow and Neurobiotin were iontophoresed into the cell with biphasic current $(1 \mathrm{nA}$, $3 \mathrm{~Hz}$ ) for 1-4 min. After several cells were filled, the retina was fixed in $4 \%$ formaldehyde for $30 \mathrm{~min}$, washed in $0.1 \mathrm{M} \mathrm{PB} / 0.5 \%$ Triton $\mathrm{X}-100 / 0.1 \%$ sodium azide, and reacted overnight with 1:100 streptavidin/Cy3.

Immunocytochemistry. Immunolabeling was performed following previously established protocols (Massey and Mills, 1996). For double- or triple-labeling experiments, flat-mount pieces of retina or free-floating vibratome sections were blocked in $3 \%$ donkey serum in PB with $0.5 \%$ Triton X-100/0.1\% sodium azide for $2 \mathrm{hr}$ to overnight to reduce nonspecific labeling. The tissue was incubated in primary antibodies in the presence of $1 \%$ donkey serum/PB with $0.5 \%$ Triton $\mathrm{X}-100 / 0.1 \%$ sodium azide for up to 1 week. The tissue was washed with $\mathrm{PB}$ containing $0.5 \%$ Triton X-100/0.1\% sodium azide and reacted with fluorescently labeled secondary antibodies overnight. Fluorochromes were Alexa 488 (Molecular Probes, Eugene, OR), Cy3, and Cy5. Preparations were mounted with Vectashield (Vector Laboratories) and viewed with a confocal microscope equipped with a krypton/argon laser (Zeiss, LSM 410). Images were adjusted using Adobe Photoshop 5.5.

Data analysis. Standard S1/S2 cells were defined based on averaged data from examples of dye-injected S1/S2 cells. Varicosities were taken as large and obvious swellings along the S1/S2 dendrites. The dendritic 
diameter was measured at $\leq 0.5 \mu \mathrm{m}$, and varicosities were counted as $>1$ $\mu \mathrm{m}$ in diameter. At the low end of this range, particularly with the smaller S2 varicosities, there is some uncertainty because there are occasional dendritic thickenings that approach this size, although they are not adjacent to rod bipolar terminals. However, objectivity could be maintained by turning off the rod bipolar channel when counting varicosities, and in addition, only the true varicosities were stained for synaptic markers and not the intervening stretches of dendrite.

The varicosities around a standard S1 or S2 were counted in a series of expanding shells. When divided by the number of rod bipolar cells in each shell, this gives the probability of contact between an RBC and a single $\mathrm{S} 1 / \mathrm{S} 2$ at a given distance. Then, centered around an RBC, this probability times the number of S1/S2 cells in each shell yields the number of S1/S2 cells that contact the rod bipolar cell shell by shell (see Fig. 10). The distribution of S1/S2 somas was plotted as background, and a custom program was used to place standard S1/S2 cells, according to the number of S1/S2 cells calculated above that contact the central rod bipolar cell, in random positions with dendrites in random directions. The results are averaged from 30-40 trials. For model A, it was assumed that regenerative dendritic properties allow signal transfer from one varicosity to all others, passing through the soma if necessary. For model $\mathrm{B}$, it was assumed that signal transfer is limited to a single dendritic branch and cannot pass the soma. On the basis of these assumptions, the program counted the number of S1/S2 varicosities in each shell that could affect the central RBCs via the dendritic structure. This also reflects the input from other rod bipolar cells and is greater for close S1/S2 cells because the proximal density of varicosities is much higher. The density of effective varicosities was plotted against distance from a single RBC (see Fig. 11).

\section{RESULTS}

\section{Triple labeling of the S1/S2 matrix, All amacrine cells,} and rod bipolar terminals

Although there is very little endogenous serotonin in the rabbit retina, once the cells are loaded with exogenous serotonin a serotonin antibody may be used effectively to visualize the S1 and S2 amacrine cells. The vast majority of cell bodies are located in the INL from which fine dendrites descend diagonally to form an extremely dense and overlapping meshwork at the bottom of the IPL (Fig. 1 $A$ ). Although dendrites of $\mathrm{S} 1$ and $\mathrm{S} 2$ cannot be distinguished, close examination of this meshwork reveals certain repeated characteristics. Embedded within overlapping regions of straight dendrites are clusters of varicosities. Double labeling with an antibody against PKC to label rod bipolar cells shows that the clusters of varicosities surround the terminals of rod bipolar cells (Fig. 1B). The rod bipolar terminals fill holes in the S1/S2 matrix, and every terminal, without exception, is surrounded by several varicosities. Visual inspection suggests that varicosities in the S1/S2 matrix only occur adjacent to rod bipolar terminals, but it is sometimes difficult to distinguish varicosities from fasciculated dendrites.

AII amacrine cells are also postsynaptic to rod bipolar cells, and the AII matrix can be visualized with an antibody against calretinin (Wässle et al., 1995; Massey and Mills, 1999). The AII matrix is sparse compared with the S1/S2 matrix, but this is expected because the overlap of AII dendrites in sublamina $b$ ranges from 3 to 8 , compared with $>70$ for $\mathrm{S} 2$ and $>500$ for S1 amacrine cells (Vaney, 1986). Nevertheless, dendrites from AII amacrine cells touch every rod bipolar terminal in the field (Fig. $1 C$ ). There are no rod bipolar terminals that are not adjacent to AII dendrites. The AII and S1/S2 matrices appear to be complementary. In the triple-label image, alternating AII (calretinin, red) and S1/S2 (serotonin, green) labeling can be observed around the rim of the rod bipolar terminals (Fig. 1D). It appears that AII dendrites frequently fill the gaps between multiple S1/S2 contacts with rod bipolar terminals. This is consistent with the
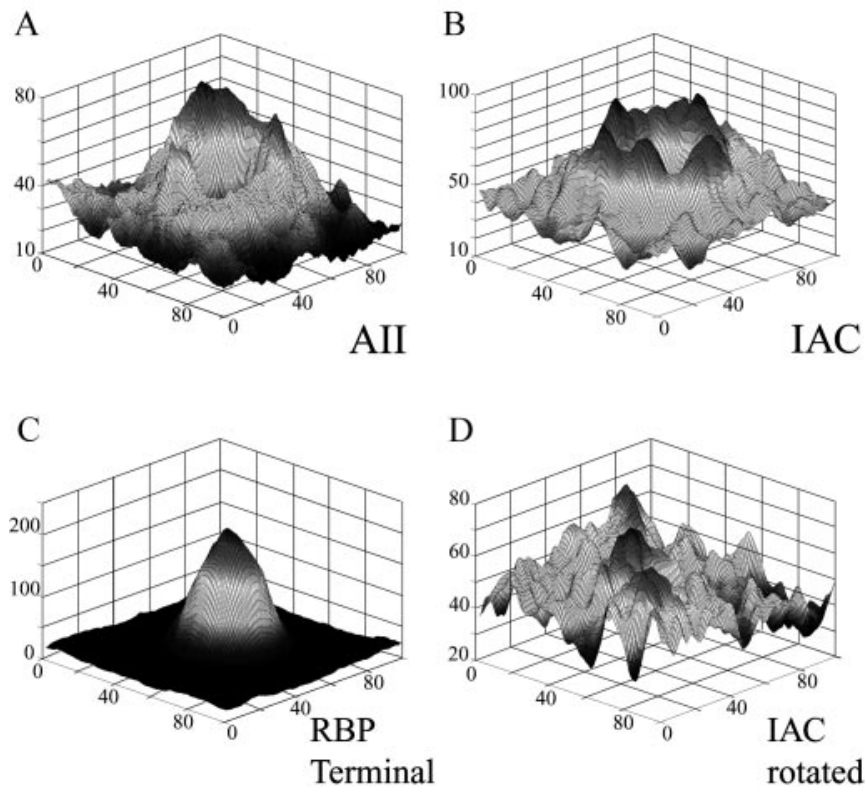

Figure 2. Image analysis of Figure 1. Surface plots show the average distribution of label in each channel around a repeated neuronal structure, in this case, rod bipolar terminals. A $50 \times 50$ image was clipped out around 35 rod bipolar terminals. This analysis shows that the apparent contacts observed in Figure 1 are real. $A$, The caldera of red pixels indicates a high probability of finding an AII process adjacent to a rod bipolar terminal. $B$, The caldera of green pixels indicates a high probability of finding an $\mathrm{S} 1 / \mathrm{S} 2$ process adjacent to a rod bipolar cell. $C$, The average distribution of blue pixels. This peak is high and uniform with very low background because the selected structures were rod bipolar terminals. This coincides with the central cavity in $A$ and $B$. $D$, As a control, the $\mathrm{S} 1 / \mathrm{S} 2$ image was rotated $180^{\circ}$ out of phase, and the same analysis was performed around rod bipolar terminals. There is no discernible structure in the plot indicating that the spatial relationship shown in $B$ has been destroyed.

postsynaptic localization of AII and $\mathrm{S} 1 / \mathrm{S} 2$ dendrites at rod bipolar terminals.

\section{Image analysis}

To avoid reliance on mere inspection, we developed a quantitative assessment of the relationship between the antibody labels shown in Figure 1. A cursor was centered on each separate rod bipolar terminal, and a $50 \times 50$ pixel box was clipped from the image. During this manual selection process, the red and green channels were turned off to reduce operator bias. These image sections were then aligned and averaged. In effect, this is a method to analyze the average distribution of labeling in the other two channels around a repeated neuronal structure. In other words, for this image, it is a method to assess the average distribution of AII and S1/S2 dendrites around rod bipolar terminals. The results are shown in Figure 2. Figure $2 C$ shows the central peak of rod bipolar terminals with very low noise because these structures were selected. Figure 2, $A$ and $B$, shows the average distribution of AII and S1/S2 [indoleamine-accumulating amacrine cells (IACs)] processes around the rod bipolar terminals. In each case, a distinct volcanic caldera occurs around a central cavity coincident with the average rod bipolar peak from Figure $2 C$. The S1/S2 caldera is smoother and more regular than the AII caldera. This may reflect the greater density of the S1/S2 matrix and a larger number of synaptic contacts. In both cases, the height of the caldera immediately adjacent to the rod bipolar 
Figure 3. Varicosities contain synaptic markers. $A$, A single prominent rod bipolar terminal stained with anti-PKC. $B$, Same field, stained for the synaptic vesicle protein SV2. The rod bipolar terminal is well stained, but there are additional lobes adjacent to the rod bipolar terminal that express SV2. $C$, Double-label image shows that the rod bipolar terminal contains both PKC and SV2 (purple), but the adjacent lobes contain only synaptophysin (red, outlined); they are not part of the rod bipolar terminal. $D$, Triple-label image. The rod bipolar terminal contains PKC and SV2 (purple), whereas the adjacent lobes are stained for serotonin and SV2 (yellow). The dendrites of the IACs are stained only for serotonin (green); they do not contain synaptic vesicles. Thus, the S1/S2 varicosities surrounding the rod bipolar terminal contain synaptic markers.
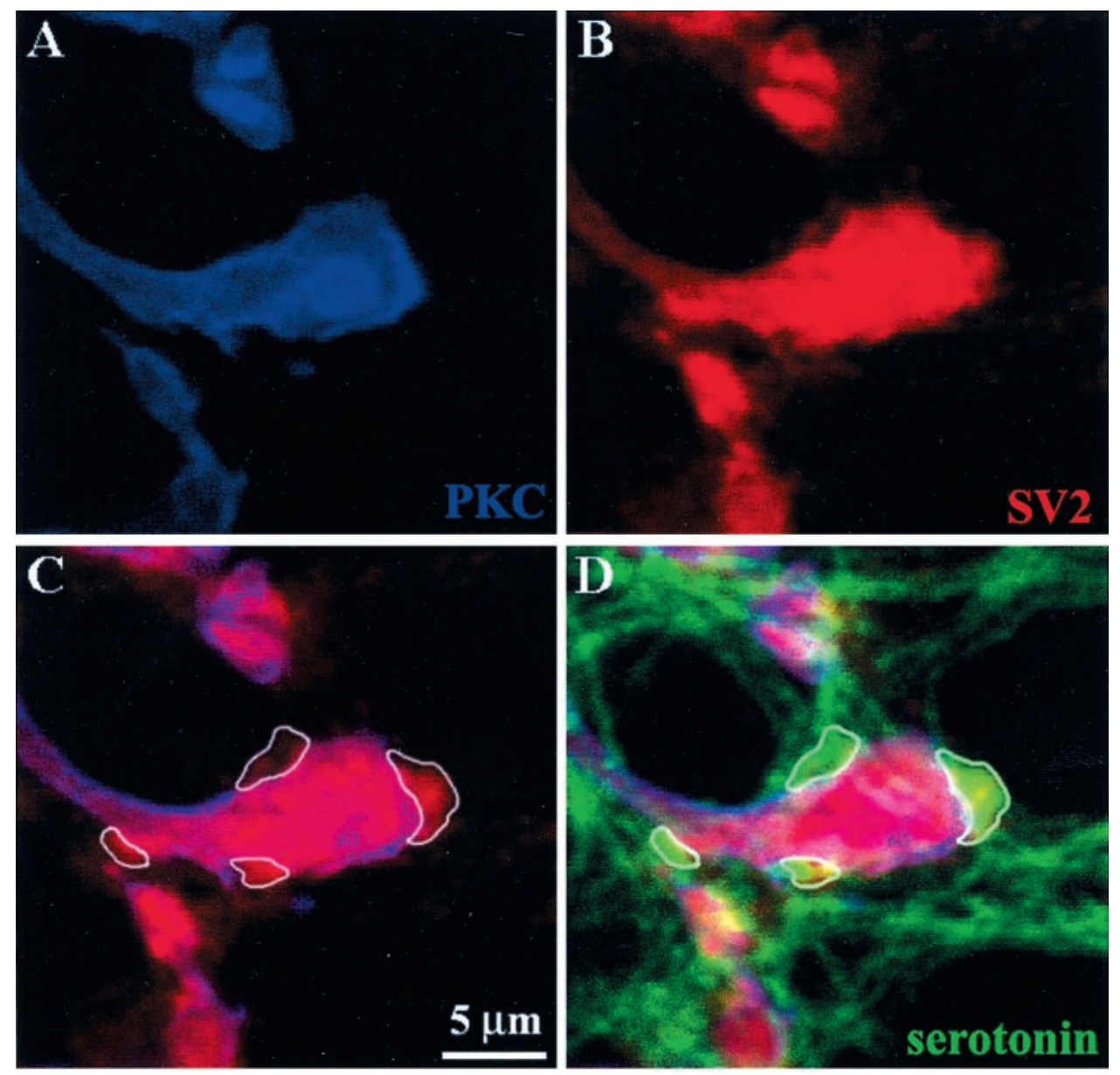

terminal far exceeds the local noise at a distance from the central cavity. This indicates that, on average, there is a high probability of encountering AII and S1/S2 processes immediately adjacent to a rod bipolar terminal. As a control, the S1/S2 image was rotated $180^{\circ}$ from the rod bipolar image. The same analysis then showed no peak with relation to the rod bipolar signal (Fig. 2D). This analysis confirms that the visual impression is real and that we can reliably visualize the contacts between rod bipolar terminals and their postsynaptic elements using confocal microscopy.

\section{Localization of synaptophysin in S1/S2 varicosities}

The analysis above suggests that the varicosities in the S1/S2 matrix are synaptic structures, and the intervening stretches of fine dendrite do not specifically associate with rod bipolar terminals. Given that S1 and S2 amacrine cells make reciprocal synapses, we examined the distribution of synaptic markers at the rod bipolar cell synapse. Synaptophysin is a protein involved in the docking of synaptic vesicles at the site of release (Brandstätter et al., 1996), and SV2 is another synaptic vesicle protein (Buckley and Kelly, 1985; Yang et al., 2002). Thus, we triple labeled some material to determine whether the varicosities around rod bipolar terminals were associated with these synaptic markers (Fig. 3).

As reported previously, SV2 labeling was found in both plexiform layers (Brandstätter et al., 1996; Yang et al., 2002). Zooming in on a single prominent example revealed that rod bipolar terminals express high levels of SV2; this is consistent with the immense number of synaptic vesicles packed into a single terminal. However, at high magnification, it can be seen that there are additional SV2-positive lobes adjacent to the rod bipolar terminal (Fig. 3B; outlined in $C$ is double labeling of $A$ and $B$ ). The triple-label in Figure $3 D$ shows that the SV2positive profiles adjacent to the rod bipolar terminals are S1 and S2 varicosities. Importantly, the intervening S1/S2 dendrites were not stained for SV2. This implies that only the $\mathrm{S} 1 / \mathrm{S} 2$ varicosities, which cluster around rod bipolar terminals, make synaptic contacts. Similar results were found for synaptophysin (data not shown).

\section{Intracellular injections}

When isolated pieces of rabbit retina were incubated with $5 \mu \mathrm{M}$ DAPI for $30 \mathrm{~min}$, various cells were labeled. Compared with the brightly labeled AII amacrine cells, somas of S1 and S2 amacrine cells were lightly stained and relatively large, $10-14 \mu \mathrm{m}$ in diameter, and located near the proximal border of the INL. Labeled cells in mid-inferior retina were chosen and dye injected with a mixture of $4 \%$ Neurobiotin and $1 \%$ Lucifer yellow. Figure $4 \mathrm{~A}$ shows part of a dye-injected S1 amacrine cell at $4 \mathrm{~mm}$ inferior. As reported previously, S1 amacrine cells had large somas with 20-25 straight radiating dendrites that descended to the dense plexus in sublamina 5 , observed when the whole population was stained (Fig. 1). The dendritic diameter of this cell was $1800 \mu \mathrm{m}$, but the diameter varied with eccentricity ranging from $1200 \mu \mathrm{m}$ at the visual streak to $>3000 \mu \mathrm{m}$ in the periphery (Vaney, 1986). In complete fills, the terminal dendrites ended abruptly without a 


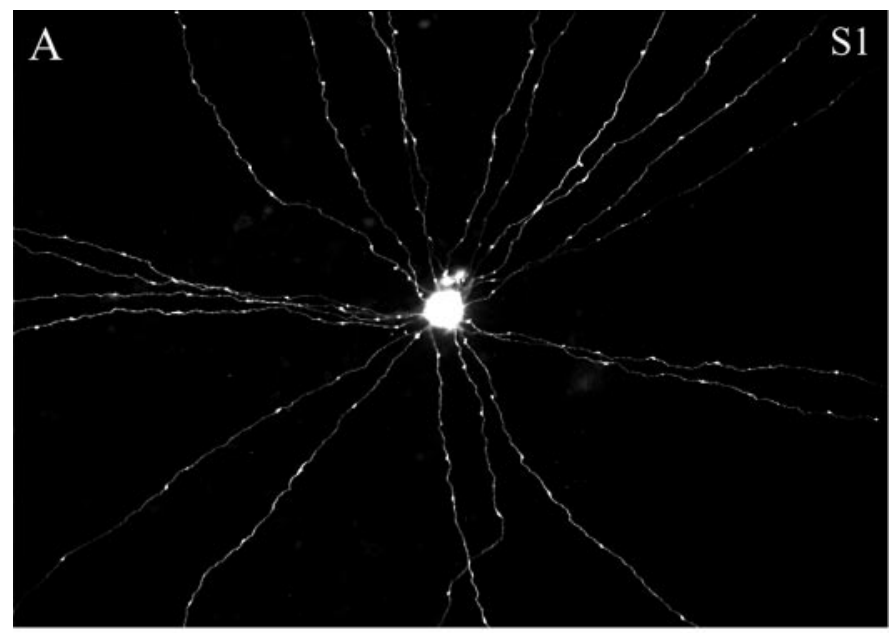

B
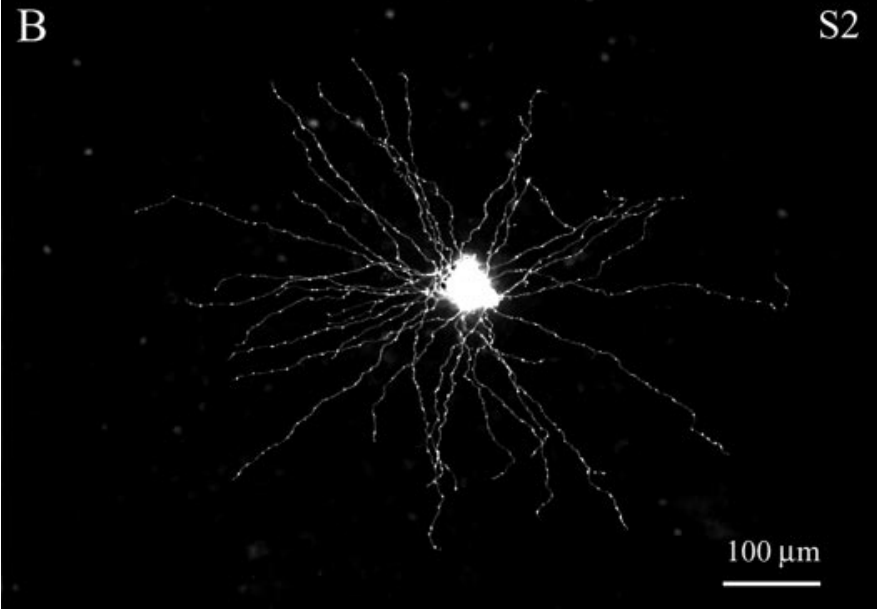

Figure 4. Indoleamine-accumulating amacrine cells from whole-mount rabbit retina filled with Neurobiotin and subsequently visualized with Cy3. $A$, An S1 amacrine cell; focus in sublamina 5 of the inner plexiform layer, adjacent to the ganglion cell layer. The center part of the cell is shown, but the distal dendrites fall outside the frame. Note the fine radiating dendrites with large widely spaced varicosities. $B$, An S2 amacrine cell. Note the smaller cell with more crossed dendrites and numerous beaded varicosities spaced more closely together.

terminal varicosity (Vaney, 1986). Partially filled cells were excluded because the dendritic labeling tapered slowly and then disappeared, so shorter lengths of dendrite were filled. There were leaf-like varicosities (diameter, 1.9-5.9 $\mu \mathrm{m}$; mean, $3.4 \pm 1.2$ $\mu \mathrm{m})$ along the entire length of each dendrite. The inter-varicosity spacing was $58 \pm 6 \mu \mathrm{m}$.

Although the structure of the S2 amacrine cell was similar to that of S1 amacrine cells, it was not hard to differentiate these two cell types. S2 amacrine cells have a smaller dendritic field (from 300 to $1000 \mu \mathrm{m}$ ) (Vaney, 1986) and tangled, rather than straight, radiating dendrites. One example of a Neurobiotin-injected S2 amacrine cell is shown in Figure $4 B$. Viewed in flat mount, its dendrites had a high density of small beaded varicosities (diameter, 0.9-2.2 $\mu \mathrm{m}$; mean, $1.4 \pm 0.4 \mu \mathrm{m})$. The mean distance between varicosities was $21 \pm 3 \mu \mathrm{m}$.

\section{$\mathrm{S} 1$ and $\mathbf{S 2}$ varicosities are adjacent to rod bipolar terminals}

Intracellular injection of single cells made it possible to visualize individual varicosities at high magnification in material that was also labeled for rod bipolar cells. An example of an S1 varicosity is shown in Figure $5 A$. It can be seen that the varicosity is immediately adjacent to a rod bipolar terminal. Within this short stack of confocal sections $(6 \times 0.5 \mu \mathrm{m}$ sections $)$, the $\mathrm{S} 1$ varicosity and the rod bipolar terminal appear to overlap, and the colocalized labels produce yellow (Fig. $5 B$ ). In fact, the two processes are separate in three-dimensional space as can be seen from another reconstructed example in Figure $5 C$. This volume rendering shows that the $\mathrm{S} 1$ varicosity is intimately wrapped around the rod bipolar terminal, and the surfaces of these two processes are adjacent (Fig. 5D). This is consistent with previous studies in which this synaptic complex was reconstructed from serial EM sections (Strettoi et al., 1990).

A similar analysis was conducted for dye-injected S2 amacrine cells, and an example is shown in Figure $5 E$, which shows a small area of radiating dendrites bearing prominent varicosities, some of which are marked by arrows. In the double-label image, all of the S2 varicosities (four of four) are adjacent to rod bipolar terminals (Fig. $5 F$ ).

A quantitative analysis was performed for three S1 and three S2 amacrine cells. Each cell was a completely filled example, as determined by the sudden end of labeling at the dendritic terminals as opposed to the slow fade that indicates an incomplete fill. This material was also double labeled with anti-PKC so that the contacts between varicosities and rod bipolar terminals could be assessed by confocal microscopy. S1 amacrine cells had a mean of 283 varicosities (individual values: 228, 257, 364; SD, 72), of which an average of 276 contacted a rod bipolar terminal. S2 amacrine cells had a higher number of varicosities (mean, 508; individual values: 395, 554, 575; SD, 98), of which an average of 499 were adjacent to a rod bipolar terminal. In total, for both S1 and S2 amacrine cells, $98 \%$ of the varicosities contacted a rod bipolar terminal. This suggests that, within the limit of experimental error, essentially all of the varicosities are adjacent to rod bipolar terminals. If the varicosities are synaptic contacts, then the only output from S1 and S2 amacrine cells is to the terminals of rod bipolar cells.

\section{One varicosity per rod bipolar cell}

$\mathrm{S} 1$ amacrine cells are larger but have fewer varicosities. Thus, the density of varicosities is higher in S2 amacrine cells. However, it was suggested previously that the intervaricosity spacing of even S2 amacrine cells exceeds the axonal field diameter of rod bipolar terminals, and therefore any given rod bipolar cell could be contacted by only one varicosity from a single S2 amacrine cell (Vaney, 1986).

To test this idea systematically, we reconstructed a patch of retina stained for PKC to identify all individual rod bipolar cells and systematically identified the contacts of dye-injected S1 or S2 amacrine cells. An example is shown in Figure 6, in which the somas of 26 rod bipolar cells were identified and followed to their axon terminal structures. Each axon terminal was outlined and numbered, and a dye-injected S1 amacrine cell was overlaid. Even three unusually close varicosities on two parallel dendrites contacted different rod bipolar cells, numbers 3, 12, and 13. Similar data were obtained for S2 amacrine cells as illustrated in Figure $5, E$ and $F$. It was rare for a single rod bipolar terminal to receive more than one varicosity, even from closely parallel dendrites. These data were confirmed by calculations that showed the intervaricosity distance to be $\sim 58 \mu \mathrm{m}$ for $\mathrm{S} 1$ and $20 \mu \mathrm{m}$ for S2 in 
Figure 5. All varicosities are adjacent to rod bipolar terminals. $A$, A highresolution view of a single S1 varicosity. The fine process trailing from the varicosity is probably a dye-coupled dendrite from another $\mathrm{S} 1$ amacrine cell. $B$, Double-label image showing the same S1 varicosity (green) adjacent to a rod bipolar terminal stained for PKC (red). $C$, A reconstruction of another $\mathrm{S} 1$ varicosity. $D$, A three-dimensional reconstruction of the same S1 varicosity showing it wrapped intimately around a rod bipolar terminal (red). E, Several dendrites from a single Neurobiotinfilled S2 amacrine cell. Several varicosities are indicated by arrows. F, Doublelabel image showing that every S2 varicosity (green, arrows) contacts a rod bipolar terminal $($ red $)$.

Figure 6. Each rod bipolar terminal is contacted by only one varicosity from a dye-injected $\mathrm{S} 1$ amacrine cell. $A$, The somas of PKC-stained rod bipolar cells, each identified and numbered. $B$, Same field, focus at the border of the IPL/ INL, shows that individual axons can be followed until the terminal fields of each rod bipolar cell are outlined $(C)$. Two parallel dendrites from a Neurobiotin-filled S1 amacrine cell are superimposed (black), and it can be seen that each varicosity contacts a separate rod bipolar terminal.
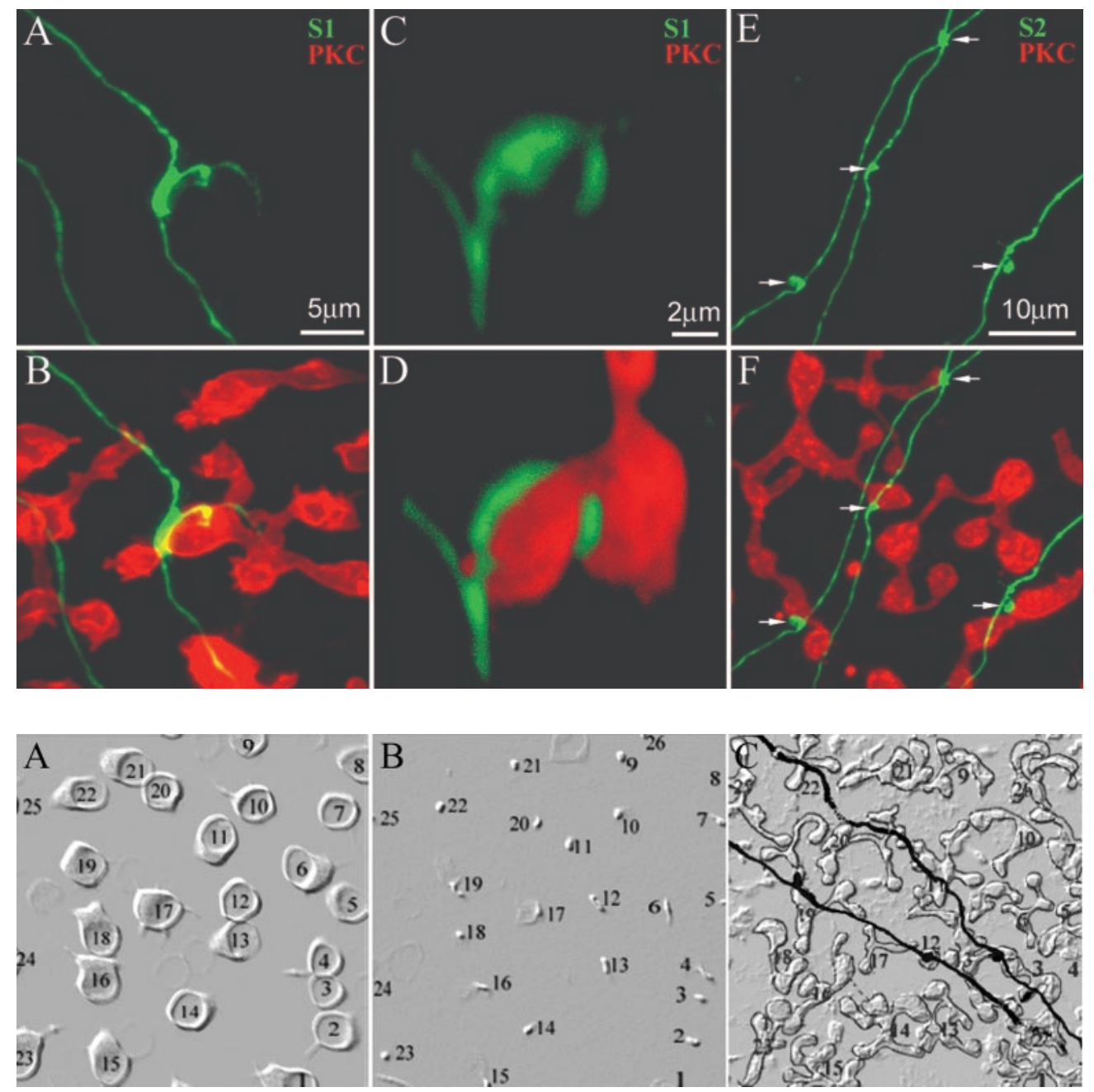

near-central retina where rod bipolar cells have an average terminal area of $100-200 \mu \mathrm{m}^{2}$ and a calculated diameter of 12-16 $\mu \mathrm{m}$ (Young and Vaney, 1991). Thus, as a general rule, on average, each S1/S2 varicosity contacts a different rod bipolar terminal. This is an important point because, as we shall see, this directly affects the distribution of S1 and S2 amacrine cells that can contact an individual rod bipolar cell.

Further calculations indicate that an S1 amacrine cell contacts $<5 \%$ of the rod bipolar cells within its dendritic field. This number is $\sim 50 \%$ for S2 amacrine cells, obviously higher by a factor of 10 . This reflects the smaller size and greater varicosity number, yielding a much higher density for S2 amacrine cells.

\section{S1/S2 varicosities are apposed to GABA receptors}

If a model of the S1/S2 synaptic output is to be based on the distribution of varicosities, then it is necessary to show that all the varicosities adjacent to rod bipolar terminals are, in fact, synapses. The above results showing the presence of synaptic markers and the reliable juxtaposition between varicosities and rod bipolar terminals suggest that this is the case. However, we also wanted to establish the presence of postsynaptic receptors at these sites. Both S1 and S2 amacrine cells are wide-field GABA amacrine cells, so it was appropriate to look for the expression of GABA receptors. Previous work has shown that bipolar cells express $\mathrm{GABA}_{\mathrm{A}}$ and $\mathrm{GABA}_{\mathrm{C}}$ receptors, both of which may be postsynaptic at some contacts with $\mathrm{S} 1$ and $\mathrm{S} 2$ amacrine cells
(Fletcher et al., 1998; Shields et al., 2000; Pan, 2001). In this case, we chose to use antibodies against the $\mathrm{GABA}_{\mathrm{C}}$ receptor to demonstrate that postsynaptic receptors are present at the appropriate location.

As shown before, varicosities in the $\mathrm{S} 1 / \mathrm{S} 2$ matrix are clustered around rod bipolar terminals. Figure $7 A$ shows the matrix of $\mathrm{S} 1$ and S2 dendrites in sublamina 5. Much of the matrix is composed of overlapping dendrites that bear no synaptic specializations, but one particularly prominent ring of varicosities is indicated by arrows. The $\mathrm{GABA}_{\mathrm{C}}$ receptors are located inside the ring of varicosities. Within the limit of confocal resolution, the S1/S2 varicosities appear to be partially colocalized, but it is still clear that the $\mathrm{GABA}_{\mathrm{C}}$ receptors extend within the circle of varicosities. Each circle of varicosities surrounds an individual rod bipolar terminal, and the triple-label image shows that rod bipolar terminals are well labeled with $\mathrm{GABA}_{\mathrm{C}}$ receptors (Fig. $7 B$, red puncta). Furthermore, the hotspots of $\mathrm{GABA}_{\mathrm{C}}$ receptors are located exclusively within the limits of the rod bipolar terminals. Comparison of the two double-label images shows that the $\mathrm{GABA}_{\mathrm{C}}$ receptors occur precisely at the sites of apposition with S1/S2 varicosities. This indicates that the S1 and S2 contacts with rod bipolar cells are coincident with the location of postsynaptic GABA receptors.

When viewed in vertically sectioned material (Fig. 7C), S1 and $\mathrm{S} 2$ cells appear as somas in the inner nuclear layer, with dendrites 

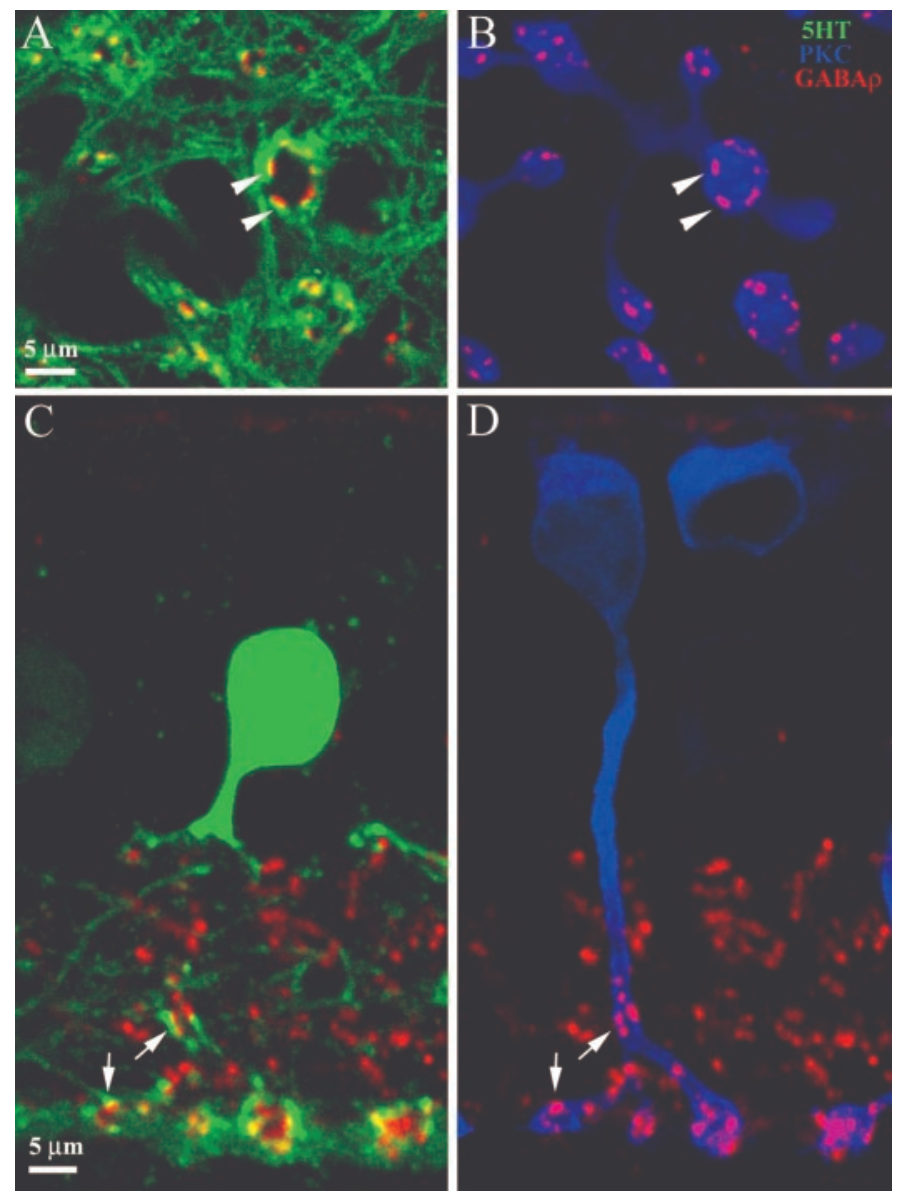

Figure 7. $\mathrm{GABA}_{\mathrm{C}}$ receptors are found at contact points between $\mathrm{S} 1 / \mathrm{S} 2$ varicosities and rod bipolar terminals. $A$, Confocal view in whole mount, focus in sublamina 5, shows the S1/S2 matrix (green) stained with a serotonin antibody after preloading. $\mathrm{GABA}_{\mathrm{C}}$ receptors $($ red $)$ are associated with a prominent cluster of $\mathrm{S} 1 / \mathrm{S} 2$ varicosities (arrowheads), which surround one lobe of a rod bipolar terminal. $B$, Same field; the rod bipolar cells, stained for PKC, are shown in blue. The lobe that fills the hole in the $\mathrm{S} 1 / \mathrm{S} 2$ matrix is labeled with $\mathrm{GABA}_{\mathrm{C}}$ receptor clusters at the points of contact with $\mathrm{S} 1 / \mathrm{S} 2$ varicosities (arrowheads). $C$, Vertical section shows a single S1 or S2 soma and numerous dendrites descending diagonally through the inner plexiform layer to form a dense matrix in sublamina 5 (green). There are many varicosities in the matrix and occasionally one high in the IPL above the level of the rod bipolar terminals (diagonal arrow). $\mathrm{GABA}_{\mathrm{C}}$ receptors (red) are found throughout the IPL, but they are particularly associated with S1/S2 varicosities in sublamina 5 (vertical arrow) and those high in the IPL (diagonal arrow). D, Same field; doublelabel image showing rod bipolar cells (blue) and $\mathrm{GABA}_{\mathrm{C}}$ receptors (red). It can be seen that the rod bipolar cell terminals are heavily labeled with $\mathrm{GABA}_{\mathrm{C}}$ receptors at the contact points with $\mathrm{S} 1 / \mathrm{S} 2$ varicosities, both in sublamina 5 and higher in the IPL (diagonal arrow). This indicates that all $\mathrm{S} 1 / \mathrm{S} 2$ varicosities contact rod bipolar terminals coincident with the expression of $\mathrm{GABA}_{\mathrm{C}}$ receptors.

descending to a thick matrix in sublamina 5. The soma in Figure $7 C$ could be either an $\mathrm{S} 1$ or an $\mathrm{S} 2$ amacrine cell. The $\mathrm{S} 1 / \mathrm{S} 2$ matrix contains prominent holes, which are the sites of large rod bipolar terminals, and the insides of these holes are lined with $\mathrm{GABA}_{\mathrm{C}}$ receptors. It can also be seen that $\mathrm{GABA}_{\mathrm{C}}$ receptors are located throughout the IPL, as reported previously (Enz et al., 1996). Many of these sites represent the terminals of cone bipolar cells, which also express $\mathrm{GABA}_{\mathrm{C}}$ receptors. Within the $\mathrm{S} 1 / \mathrm{S} 2$ matrix, however, there are particularly large and prominent clusters of $\mathrm{GABA}_{\mathrm{C}}$ receptors. In Figure $7 D$, we projected almost an entire rod bipolar cell from a stack of confocal images, and as reported previously, the rod bipolar terminals are heavily covered with $\mathrm{GABA}_{\mathrm{C}}$ receptors. Comparison of $C$ and $D$ in Figure 7 shows that the rod bipolar terminals occupy the holes in the S1/S2 matrix.

Most of the $\mathrm{GABA}_{\mathrm{C}}$ receptors above the $\mathrm{S} 1 / \mathrm{S} 2$ matrix occur on cone bipolar cells, but occasionally there are $\mathrm{GABA}_{\mathrm{C}}$ receptors high on a rod bipolar cell above the terminal branch point. The S1/S2 descending dendrites appear as short cross sections in this view, but occasionally a large varicosity occurs high in the inner plexiform layer (Fig. 7C, diagonal arrow). These varicosities are also coincident with $\mathrm{GABA}_{\mathrm{C}}$ receptors localized to the rod bipolar axon (Fig. 7D, diagonal arrow, same location).

In the immunolabeled material, we were unable to distinguish between S1 and S2 amacrine cells, so triple-label material was also prepared using dye-injected single cells. In this material, rod bipolar contacts with individual varicosities can be imaged at high resolution. Figure $8, A$ and $C$, shows the previously reported expression of $\mathrm{GABA}_{\mathrm{C}}$ receptors in rod bipolar terminals. In Figure $8 B$, it can be seen that where a single $\mathrm{S} 1$ varicosity is adjacent to a rod bipolar terminal, it is coincident with a $\mathrm{GABA}_{\mathrm{C}}$ receptor cluster (arrow). In Figure $8 D$, there are five $\mathrm{S} 2$ varicosities, and each one is exactly aligned with a $\mathrm{GABA}_{\mathrm{C}}$ receptor cluster on a rod bipolar terminal. This was invariably the case, as shown by high-power confocal images: 35 of $35 \mathrm{~S} 1$ varicosities contacted rod bipolar cells at $\mathrm{GABA}_{\mathrm{C}}$ receptor clusters, and 46 of $46 \mathrm{~S} 2$ varicosities were coincident with $\mathrm{GABA}_{\mathrm{C}}$ receptors. We conclude that all $\mathrm{S} 1$ and $\mathrm{S} 2$ varicosities are apposed by $\mathrm{GABA}_{\mathrm{C}}$ receptors expressed in rod bipolar terminals.

\section{High varicosities are adjacent to rod bipolar axons}

One example of an S1 or S2 varicosity high in the inner plexiform layer occurred in Figure 7, $C$ and $D$, but a much clearer picture can be obtained by examining this material in whole mount. If the level of focus is at the midlevel of the inner plexiform layer, above the branch point of the rod bipolar cells, it can be seen that some of the descending dendrites of S1 and S2 amacrine cells bear varicosities. Double-label material shows that these varicosities are invariably apposed to the axons of rod bipolar cells, which appear as dots at this level (Fig. 9A). In fact, almost every axon is contacted in this way. Occasionally, there is a cluster of two or three varicosities at the same axon (Fig. $9 A$, arrows). In a doublelabel vertical section, a few varicosities on rod bipolar axons can be seen high in the inner plexiform layer (Fig. 9B, arrows). These varicosities are apposed to $\mathrm{GABA}_{\mathrm{C}}$ receptors on the axons of rod bipolar cells (Fig. 7D).

\section{The distribution of S1 and S2 amacrine cells with input to a single rod bipolar cell}

The above evidence, together with previous reconstructions of indoleamine-accumulating amacrine cells, suggests that the varicosities of S1 and S2 amacrine cells are synaptic structures. On the basis of this assumption and with the knowledge of cell densities and the number of varicosities, we can estimate the number and distribution of reciprocal inputs to rod bipolar terminals. Close to half of the total IACs are S1 cells, and the remainder are S2 amacrine cells. The density of IACs at $1 \mathrm{~mm}$ inferior was $\sim 830$ cells per square millimeter. Multiplying by the average number of varicosities (280 for S1; 500 for S2) yields $120,000 \mathrm{~S} 1$ and 210,000 S2 for a total of 330,000 varicosities per square millimeter. Dividing by the rod bipolar density at $1 \mathrm{~mm}$ 

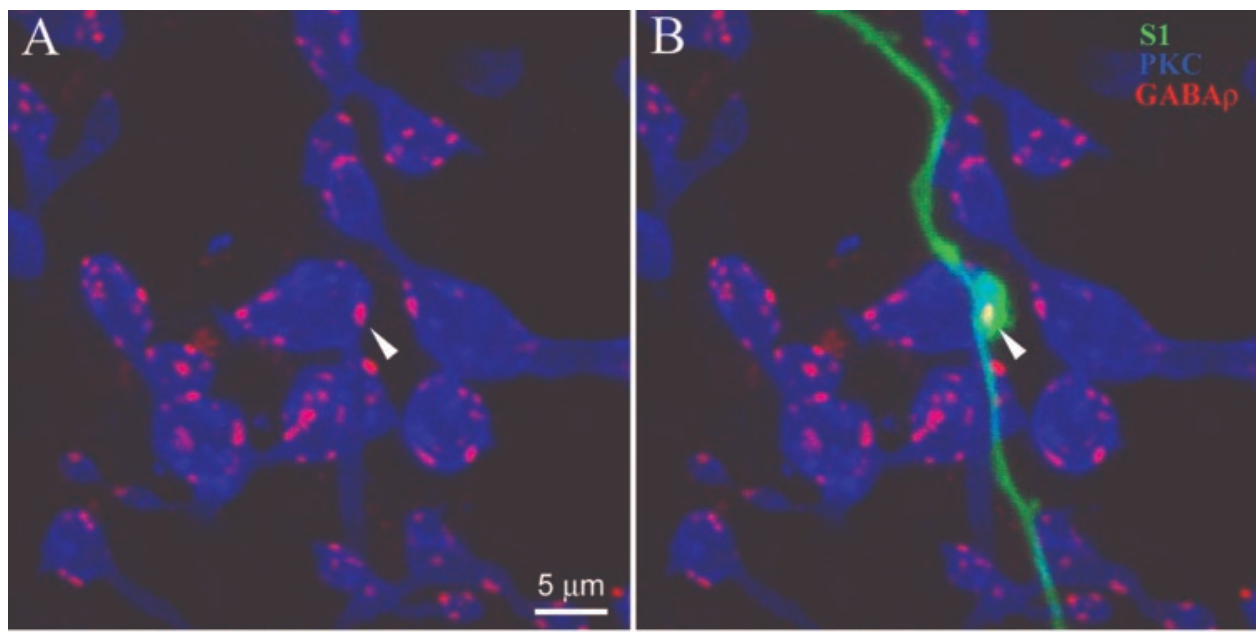

Figure 8. S1 and S2 varicosities are apposed by $\mathrm{GABA}_{\mathrm{C}}$ receptors on rod bipolar terminals. $A$, Rod bipolar terminals (blue) express $\mathrm{GABA}_{\mathrm{C}}$ receptors (red). At this level of the IPL, sublamina 5, nearly all of the $\mathrm{GABA}_{\mathrm{C}}$ clusters are associated with rod bipolar terminals. $B$, Triple-label image shows that individual varicosities from a Neurobiotin-injected S1 amacrine cell (green) overlie $\mathrm{GABA}_{\mathrm{C}}$ receptors (red) at the point of contact (arrowhead) with the rod bipolar terminal (blue). $C$, Another field showing $\mathrm{GABA}_{\mathrm{C}}$ receptors (red) on rod bipolar terminals (blue). D, Triplelabel image shows that all varicosities from a Neurobiotin-injected S2 amacrine cell (green) are associated with $\mathrm{GABA}_{C}$ receptors at contact points (arrows) with rod bipolar cells.
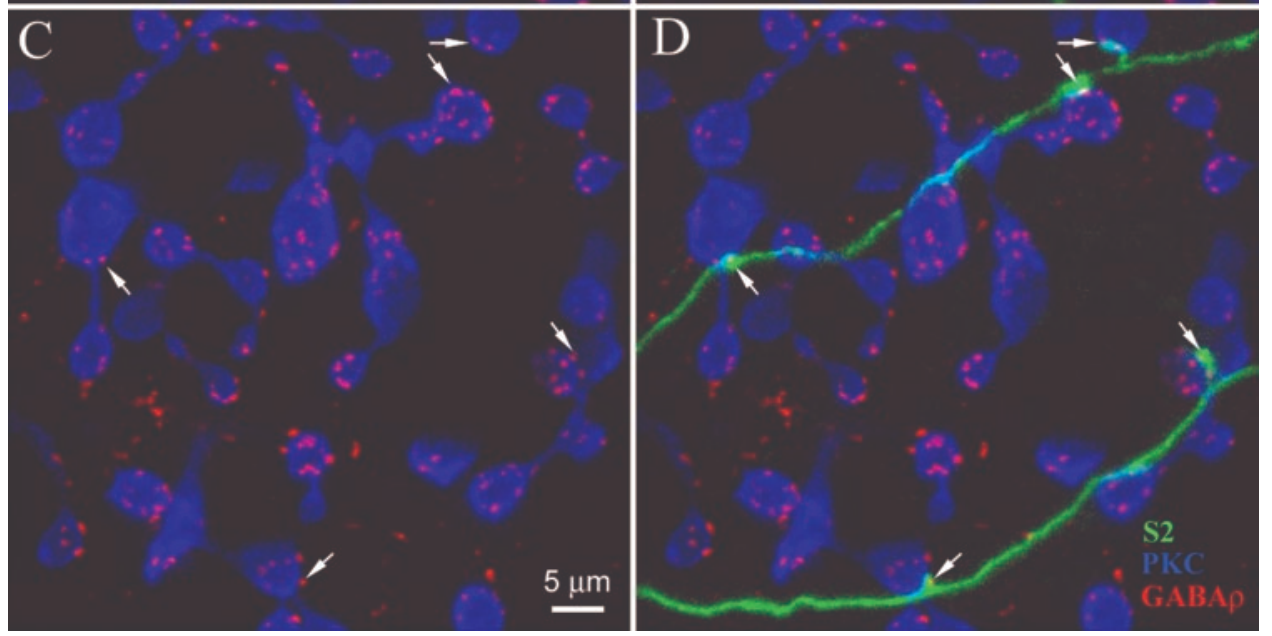

inferior (4400 per square millimeter) indicates that each rod bipolar cell, on average, receives contacts from $27 \mathrm{~S} 1$ and $48 \mathrm{~S} 2$ cells or 75 total varicosities (in round numbers, $25 \mathrm{~S} 1$ and $50 \mathrm{~S} 2$ ). This is in good agreement with a confocal estimate of total varicosities adjacent to a single rod bipolar terminal. Because, on average, each varicosity contacts a different rod bipolar cell, this means that each rod bipolar cell receives input from $\sim 25$ different $\mathrm{S} 1$ amacrine cells and 50 different S2 amacrine cells.

To construct an anatomically realistic model, we took the actual distribution of all S1 and S2 amacrine cells, identified by serotonin labeling, in a patch of retina at an eccentricity of $1 \mathrm{~mm}$. Within this population, the S1 amacrine cells were identified by tracer coupling after the intracellular injection of several S1 amacrine cells (Li et al., 2002b). The mosaics of S1 and S2 amacrine cells are plotted in the background of Figure 10. Next, we calculated the number of varicosities in a series of expanding shells around an S1 and an S2 soma. Presuming that the dendrites are linear (very close to true for S1 and a reasonable approximation for S2), these numbers are fairly constant but fall off dramatically in terms of density, yielding a falling probability of hitting a single rod bipolar cell. Now, considering a single rod bipolar cell and all the S1/S2 cells within a dendritic diameter, we can calculate the probability of hits from the $\mathrm{S} 1$ and $\mathrm{S} 2$ cells in an expanding series of shells (Fig. 10A,B). This results in a relatively even distribution across the shells, because although the individual probability falls, a far greater number of potential amacrine cells are in the farthest shells.
Several immediate consequences arise from the size and geometry of S1 versus S2 amacrine cells. First, the contributing S2 amacrine cells are more numerous and much closer because they have smaller dendritic trees. Second, because they also have more varicosities, yielding a much higher density, nearly all of the S2 amacrine cells within $200 \mu \mathrm{m}$ of a single rod bipolar cell contact that cell (Fig. 10B). These two factors mean that inhibitory inputs from nearby S2 amacrine cells are numerically dominant.

Third, nearby varicosities are sites of excitatory input (from other rod bipolar cells), which will generate an antagonistic surround. Therefore, we also calculated the distribution of varicosities for all of the S1 and S2 amacrine cells connected to a single rod bipolar cell. This has a sharpening effect over the simple overlap of contributing cells, particularly for S2 amacrine cells, because of the high density of varicosities and their proximity. The density of close-in varicosities, near an S2 soma, is much higher than the density around a peripheral varicosity from the large dendritic tree of an S1 amacrine cell (Fig. 10D). With the assumption that a signal generated from one varicosity could pass through the whole cell because of its dendritic regenerative property (Fig. $11 A$, inset), the calculation yields the curves shown in Figure $11 A$. The $\mathrm{S} 2$ curve has a greater influence close to the rod bipolar cell but falls off rapidly, whereas the distant portion of the curve is accounted for by S1 varicosities. The half-width at halfheight for the combined curves is $210 \mu \mathrm{m}$.

This presumes that all distant varicosities can contribute equally to the output at any site, an unlikely possibility given the 

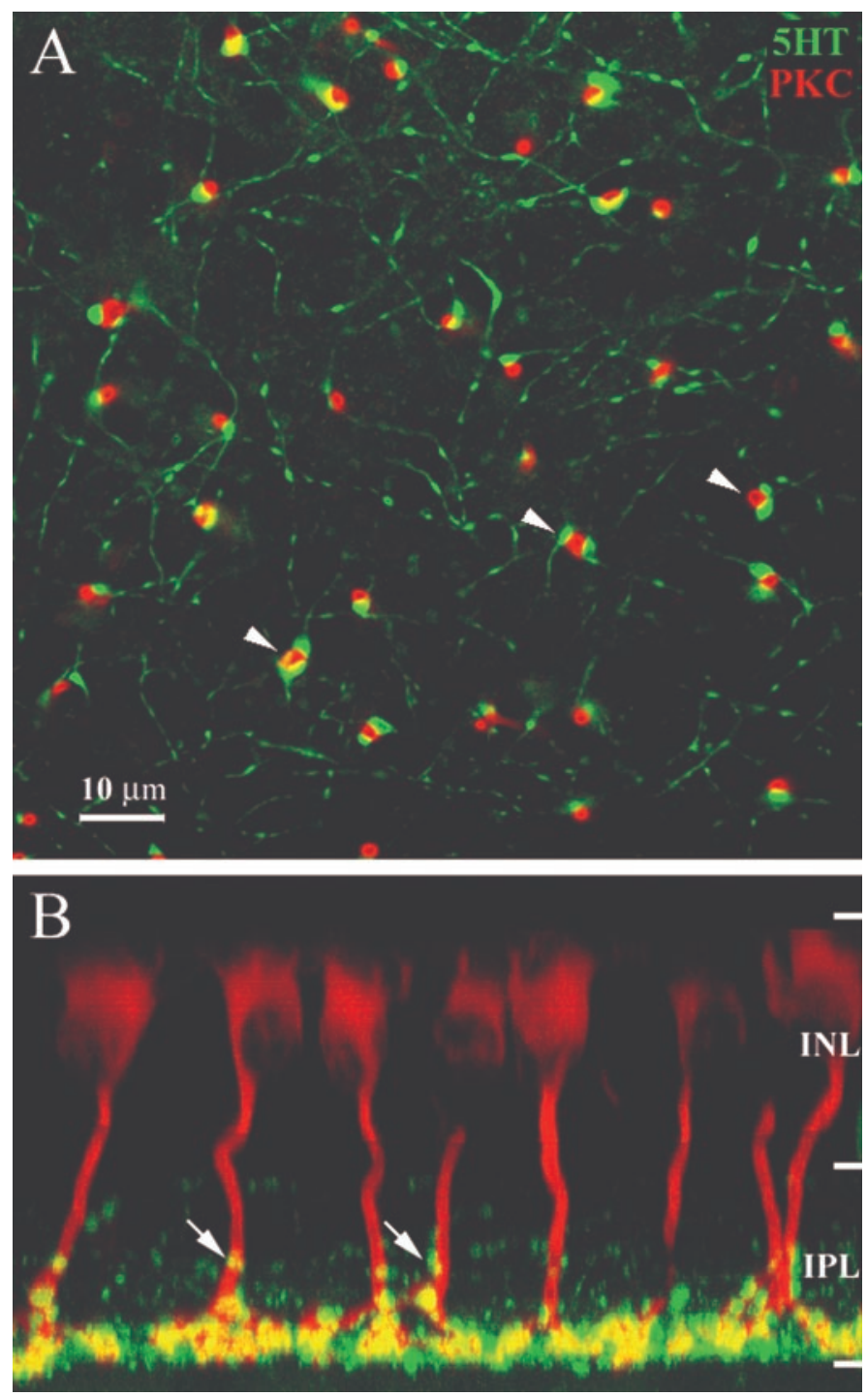

Figure 9. High S1/S2 varicosities are adjacent to rod bipolar axons. $A$, Confocal view of whole-mount retina at the midlevel of the inner plexiform layer shows the descending axons of rod bipolar cells, stained for PKC (red). At this level, S1 and S2 amacrine cells, stained with a serotonin (5HT) antibody after preloading ( green), have sparse, diagonally descending dendrites and a few large varicosities. Without exception, these large varicosities are wrapped around the rod bipolar axons (arrowheads). $B$, Similar preparation; vertical section shows rod bipolar axons (red) contacted by occasional S1/S2 varicosities ( green) at the midlevel of the IPL (arrows). Overlap in this confocal stack of images results in yellow, where the rod bipolar terminal are embedded in the $\mathrm{S} 1 / \mathrm{S} 2$ matrix in sublamina 5, and at the contact points of varicosities with rod bipolar axons.

wide-field morphology of these cells. If the contributing varicosities are restricted to those on the dendrite that contacts the rod bipolar cell (Fig. 11B, inset), the distribution curves are sharpened further (Fig. $11 B$ ). Now the half-width at half-height for the combined curves is reduced to $100 \mu \mathrm{m}$. This calculation suggests that the peak for lateral inhibitory input to a rod bipolar cell via $\mathrm{S} 1$ and S2 amacrine cells falls within a circle of $100 \mu \mathrm{m}$ radius. This is comparable with the size of the inhibitory surround of AII amacrine cells in the rod pathway (Bloomfield and Xin, 2000; Volgyi et al., 2002).

\section{DISCUSSION}

\section{Varicosities are synaptic contacts}

Chemical neurotransmission, the dominant form of communication in the CNS, occurs at synapses. These are specialized structures, and typically the presynaptic machinery resides in a swelling or out-pocketing of the presynaptic neuron. S1 and S2 varicosities are synaptic structures because (1) they contain presynaptic markers such as SV2 (Fig. 3) and synaptophysin, and (2) essentially every varicosity is intimately associated with a rod bipolar terminal, like a hand grasping a wrist (Masland and Raviola, 2000). This is a systematic and repeated pattern of neuronal contacts indicating synaptic function. (3) GABA receptors are present on the rod bipolar terminal, postsynaptic to every varicosity. We chose to examine the distribution of $\mathrm{GABA}_{\mathrm{C}}$ receptors, but $\mathrm{GABA}_{\mathrm{A}}$ receptors are also present at these sites (Fletcher and Wässle, 1999). The close association between S1/S2 varicosities and rod bipolar terminals strongly suggests an interaction, but the location of a third receptor marker exactly at these contact points establishes the presence of synaptic input (Masland and Raviola, 2000). (4) In triple-label material, the S1 and S2 varicosities alternate with AII dendrites surrounding rod bipolar terminals, as in the majority of postsynaptic pairs (Strettoi et al., 1990). (5) Rod bipolar cells use glutamate, and glutamate receptors are present at the contacts between rod bipolar cells and S1/S2 amacrine cells (Ghosh et al., 2001; Li et al., 2002a). (6) Finally, the varicosities are apposed to synaptic ribbons in the rod bipolar terminal (our unpublished observation).

These results are entirely consistent with serial reconstructions in several species that show extensive reciprocal input from GABA amacrine cells to rod bipolar terminals (Strettoi et al., 1990; Chun et al., 1993). Because of the intermediate resolution of confocal microscopy, this analysis can now be extended to include all of the varicosities made by $\mathrm{S} 1$ and $\mathrm{S} 2$ amacrine cells. Varicosities can be recognized easily using the confocal microscope, and as the hallmark of $\mathrm{S} 1 / \mathrm{S} 2$ output, a model of all reciprocal input to rod bipolar cells synapses may be developed.

\section{S1 and S2 amacrine cell output goes to rod bipolar terminals only}

The identification of S1/S2 varicosities as presynaptic sites makes it possible to identify the total output from S1 and S2 amacrine cells to rod bipolar cells. When the varicosities were examined in double-label material, we found that $>98 \%$ of varicosities are adjacent to rod bipolar terminals. Within the limit of experimental error, this means that essentially all of the S1 and S2 output goes to rod bipolar cells.

There are also occasional S1/S2 varicosities above the rod bipolar terminals. This location led to the suggestion that these high varicosities could have input to another target, perhaps a subtype of cone bipolar cell (Fletcher and Wässle, 1999). However, double-label images show clearly that the high varicosities are adjacent to rod bipolar axons (Fig. 9), and, in addition, $\mathrm{GABA}_{\mathrm{C}}$ receptors are present at these sites (Fig. 7). In fact, nearly every rod bipolar axon is contacted in this way. However, these inputs are relatively few in number: one or two varicosities of $\sim 75$ inputs to the entire rod bipolar terminal. Thus, the inputs to the axon account for only $1-2 \%$ of the $\mathrm{S} 1 / \mathrm{S} 2$ input to rod bipolar cells. Occasionally, such high synapses, above the branch point of a rod bipolar terminal, were also noted in serial reconstructions (Strettoi et al., 1990). The significance of such GABA inputs to the rod bipolar axon is unknown; these synapses might be well placed to veto signal transfer to the rod bipolar terminal, 
Figure 10. Modeling of S1 and S2 inputs to a single rod bipolar cell. $A$, A single rod bipolar cell (axon terminal, black) is positioned at the center of the field containing S1 somas (light gray). The field is divided into a series of expending shells $100 \mu \mathrm{m}$ wide. In each shell, a group of S1 cells that could reach the central rod bipolar cell is circled out. $B$, Same analysis for S2 cells (dark gray). The $\mathrm{S} 2$ cells that could contact the central rod bipolar cell are indicated by the squares. $C, \mathrm{~A}$ combined image of $A$ and $B$ shows both $\mathrm{S} 1$ and $\mathrm{S} 2$ inputs to the central rod bipolar cell. $D$, An S1 cell (left) and an S2 cell (right) are presented in the same field. The varicosities from both cells are enlarged by black dots for illustration purpose. The comparison of two circles depicts the big difference in varicosity density between $\mathrm{S} 1$ and $\mathrm{S} 2$ cells.

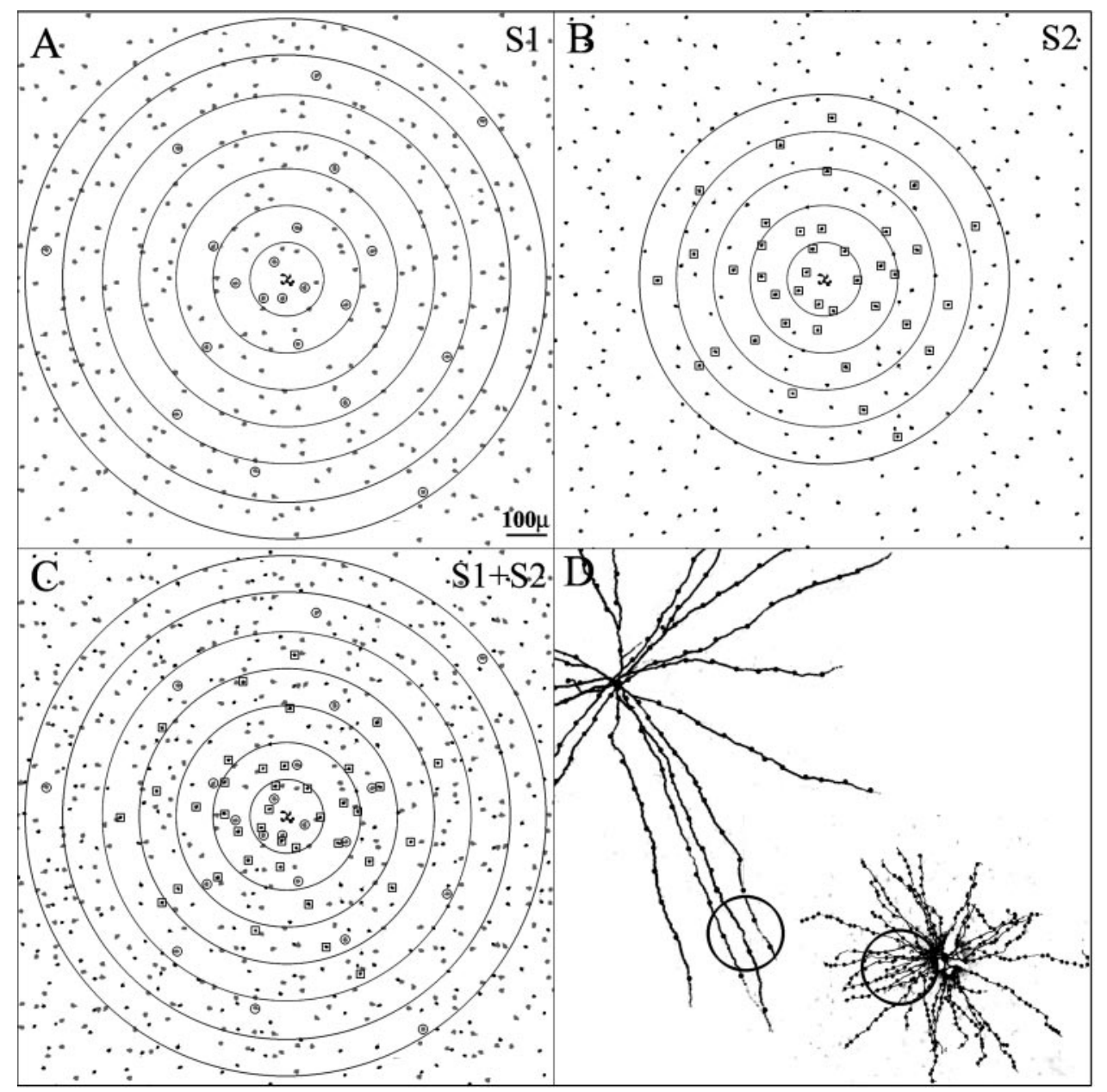

or they could merely be outliers from the majority of reciprocal synapses. In either case, including the high varicosities, all of the output from S1 and S2 amacrine cells goes to rod bipolar cells. In summary, rod bipolar cells are the only postsynaptic target for S1/S2 amacrine cells.

\section{Role of reciprocal feedback}

Serial reconstruction has established that S1 and S2 amacrine cells receive input from rod bipolar cells with which they make extensive reciprocal contacts. The results in this paper directly confirm the previous EM results and, in addition, provide a numerical estimate of this inhibitory input as well as the relative contributions of S1 and S2 amacrine cells. The estimate of 75 total $\mathrm{S} 1 / \mathrm{S} 2$ inputs is in good agreement with previous work (Fletcher and Wässle, 1999). There is additional conventional synaptic input to rod bipolar cells from unidentified amacrine cells (Strettoi et al., 1990; Bloomfield and Dacheux, 2001). However, depolarization of rod bipolar terminals induced IPSCs blocked by GABA antagonists, suggesting that they are mediated by reciprocal synaptic inputs such as those made by S1 and S2 amacrine cells (Protti and Llano, 1998; Hartveit, 1999; Matsui et al., 2001).

Reciprocal input to the rod bipolar terminal is mediated by both $\mathrm{GABA}_{\mathrm{A}}$ and $\mathrm{GABA}_{\mathrm{C}}$ receptors apposed to $\mathrm{S} 1 / \mathrm{S} 2$ varicosities. $\mathrm{GABA}_{\mathrm{C}}$ receptors are located predominantly on bipolar cells where they mediate a powerful and sustained inhibitory input
(Enz et al., 1996; Fletcher and Wässle, 1999; Shields et al., 2000). In contrast, $\mathrm{GABA}_{\mathrm{A}}$ receptors are distributed more widely, and they produce a rapid and transient response in bipolar cells (Shields et al., 2000). However, there is no simple relationship such that $\mathrm{S} 1$ input is mediated by one type of GABA receptor and $\mathrm{S} 2$ by another. Both GABA receptors occur postsynaptically at S1 and S2 varicosities, but probably not at the same synapse (Fletcher et al., 1998; Fletcher and Wässle, 1999).

Intracellular recordings from rod bipolar cells, perhaps surprisingly, showed no surround responses (Berntson and Taylor, 2000; Bloomfield and Xin, 2000). However, rod signals in AII amacrine cells have a small inhibitory surround with interesting pharmacological properties: it is blocked by GABA antagonists and reduced by tetrodotoxin (Bloomfield and Xin, 2000; Volgyi et al., 2002). Spiking amacrine cells in the inner retina have also been shown to generate surround components of retinal ganglion cells (Cook and McReynolds, 1998; Taylor, 1999; Flores-Herr et al., 2001). These results led Bloomfield and Xin (2000) to suggest that a spiking GABA amacrine cell such as $\mathrm{S} 1$ generates the AII surround. Furthermore, an internal block of chloride channels in the AII did not block surround activity, implying that surround inhibition is mediated by reciprocal inputs to the rod bipolar terminal (Volgyi et al., 2002).

The present results support this suggestion in several ways. (1) We have demonstrated that all S1 and S2 output goes to rod bipolar terminals. (2) S1/S2 input to rod bipolar cells is mediated 

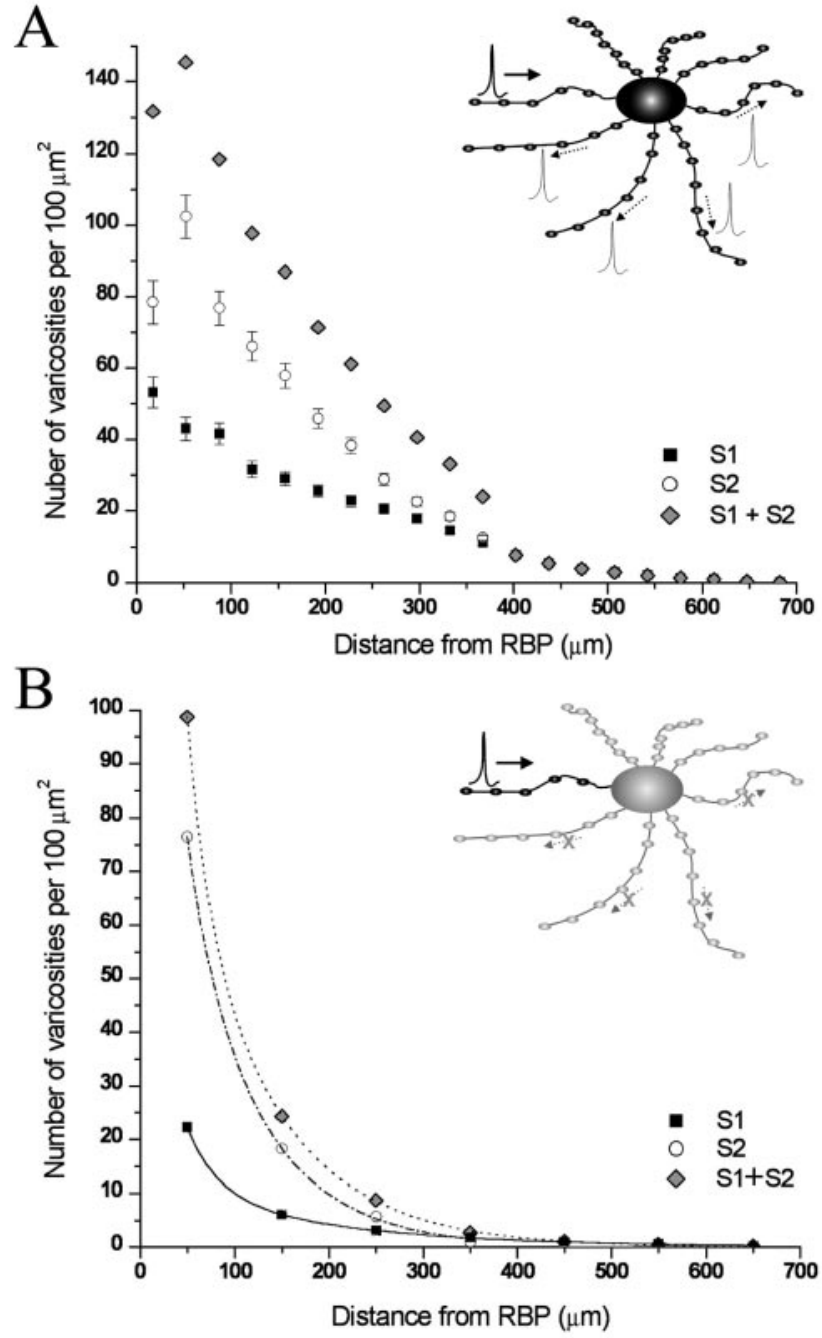

Figure 11. Profiles of feedback from S1 or S2 cells, or both, to a single rod bipolar cell. $A$, The density of varicosities from $\mathrm{S} 1 / \mathrm{S} 2$ cells that give input to a single rod bipolar cell is plotted against the distance from that single rod bipolar cell, with the assumption that signal generated by a varicosity can pass through the whole cell as demonstrated by the inset. $B$, Density of varicosities from S1/S2 cells that give input to a single rod bipolar cell is plotted against the distance from that single rod bipolar cell, with the assumption that signal generated by a varicosity can only propagate along the dendrite that contains this varicosity $(B$, inset $)$. For both $A$ and $B$, black squares represents $\mathrm{S} 1$ input, open circles represents $\mathrm{S} 2$ input, and gray diamonds represents combined inputs from S1 and S2 cells. The contours of the plot represent the spatial profiles of the feedback surround from S1 and/or S2 cells to rod bipolar cell. by GABA receptors. (3) This is a large and powerful inhibitory input derived from a dense matrix of $\mathrm{S} 1$ and $\mathrm{S} 2$ processes. (4) Modeling the distribution of S1 and S2 varicosities shows that nearby reciprocal synaptic input to rod bipolar cells is dominated by $\mathrm{S} 2$ amacrine cells. This yields an estimate of $100 \mu \mathrm{m}$ for the radius of the inhibitory surround, much smaller than the size of $\mathrm{S} 1$ amacrine cells in particular. This matches well with physiological measurements of the AII surround (Bloomfield and Xin, 2000; Volgyi et al., 2002).

\section{$\mathrm{S1}$ and $\mathrm{S} 2$ amacrine cells must provide different components}

The presence of two amacrine cell types, seemingly with the same synaptic contacts, has always been puzzling. In every case so far, however, retinal cells with different morphologies have distinct functional roles (Masland and Raviola, 2000). The analysis presented in this paper indicates that there are substantial differences between S1 and S2, summarized in Table 1, which indicate that they play different roles. In summary, the morphology and especially the distribution of varicosities suggest that S2 cells must dominate the lateral inhibitory input close to the rod bipolar cell. In contrast, the $\mathrm{S} 1$ cells provide a more distant signal that may also be distributed through a well coupled S1 network (Vaney, 1994; Xin and Bloomfield, 1997; Li et al., 2002b).

Thus, we propose that there are three components of GABAmediated inhibitory input at rod bipolar terminals. The first, which we will call local reciprocal feedback, will be very rapid or immediate because of the architecture of reciprocal synapses. It will be large, originating from all S1 and S2 varicosities, and transient, with the same spatial properties as the rod bipolar input. It will not carry surround signals but instead will provide the classic attributes of negative feedback, stability, increased frequency, and wider bandwidth. The second component will operate at medium range, within $\sim 200 \mu \mathrm{m}$. This component will be numerically dominated by $\mathrm{S} 2$ inputs and provide the inhibitory surround for the rod pathway. The third component, which we will call global or network inhibition, will arise from distant inputs. It will be dominated by S1 amacrine cells because of their larger size and extensive coupling (Vaney, 1994; Xin and Bloomfield, 1997; Li et al., 2002). S2 amacrine cells will have little contribution because of their small size and weak coupling. Together, these three components will modulate the spatial and temporal properties of rod bipolar output. This analysis also suggests that the presence of both S1 and S2 amacrine cells is not redundant, but each cell has the appropriate morphology to contribute different spatial components of lateral inhibition in the rod pathway.

Table 1. Summary of important differences between S1 and S2

S1

Very wide field

$>500$

$\sim 280$, large

$\sim 60$

Intervaricosity spacing

Varicosity density

$\%$ rod bipolar cells contacted within dendritic field

Varicosities per rod bipolar cell

Coupling

Glutamate receptors

$\%$ input within $200 \mu \mathrm{m}$ from a rod bipolar cell
120,000 per square millimeter

$5 \%$

$\sim 25$

Strong

$\Delta 1 / 2$

$\sim 20$
S2

Wide field

$\sim 70$

$\sim 500$, small

$\sim 20$

210,000 per square millimeter

$57 \%$

$\sim 50$

Weak

Unknown (Kainate?)

$\sim 80$ 


\section{REFERENCES}

Ames AD, Nesbett FB (1981) In vitro retina as an experimental model of the central nervous system. J Neurochem 37:867-877.

Berntson A, Taylor WR (2000) Response characteristics and receptive field widths of on-bipolar cells in the mouse retina. J Physiol (Lond) 524:879-889.

Bloomfield SA (1996) Effect of spike blockade on the receptive-field size of amacrine and ganglion cells in the rabbit retina. J Neurophysiol 75:1878-1893.

Bloomfield SA, Dacheux RF (2001) Rod vision: pathways and processing in the mammalian retina. Prog Retin Eye Res 20:351-384.

Bloomfield SA, Xin D (2000) Surround inhibition of mammalian AII amacrine cells is generated in the proximal retina. J Physiol (Lond) 523:771-783.

Brandstätter JH, Lohrke S, Morgans CW, Wässle H (1996) Distributions of two homologous synaptic vesicle proteins, synaptoporin and synaptophysin, in the mammalian retina. J Comp Neurol 370:1-10.

Buckley K, Kelly RB (1985) Identification of a transmembrane glycoprotein specific for secretory vesicles of neural and endocrine cells. J Cell Biol 100:1284-1294.

Chun MH, Han SH, Chung JW, Wässle H (1993) Electron microscopic analysis of the rod pathway of the rat retina. J Comp Neurol 332:421-432.

Cook PB, McReynolds JS (1998) Lateral inhibition in the inner retina is important for spatial tuning of ganglion cells. Nat Neurosci 1:714-719.

DeVries SH, Baylor DA (1995) An alternative pathway for signal flow from rod photoreceptors to ganglion cells in mammalian retina. Proc Natl Acad Sci USA 92:10658-10662.

Enz R, Brandstätter JH, Wässle H, Bormann J (1996) Immunocytochemical localization of the $\mathrm{GABA}_{\mathrm{C}}$ receptor $\rho$ subunits in the mammalian retina. J Neurosci 16:4479-4490.

Fletcher EL, Wässle H (1999) Indoleamine-accumulating amacrine cells are presynaptic to rod bipolar cells through $\mathrm{GABA}(\mathrm{C})$ receptors. J Comp Neurol 413:155-167.

Fletcher EL, Koulen P, Wässle H (1998) GABAA and GABAC receptors on mammalian rod bipolar cells. J Comp Neurol 396:351-365.

Flores-Herr N, Protti DA, Wässle H (2001) Synaptic currents generating the inhibitory surround of ganglion cells in the mammalian retina. J Neurosci 21:4852-4863.

Ghosh KK, Haverkamp S, Wässle H (2001) Glutamate receptors in the rod pathway of the mammalian retina. J Neurosci 21:8636-8647.

Hartveit E (1999) Reciprocal synaptic interactions between rod bipolar cells and amacrine cells in the rat retina. J Neurophysiol 81:2923-2936.

Li W, Trexler EB, Massey SC (2002a) Glutamate receptors at rod bipolar ribbon synapses in the rabbit retina. J Comp Neurol 448:230-248.

Li W, Zhang J, Massey SC (2002b) Coupling pattern of S1 and S2 amacrine cells in the rabbit retina. Vis Neurosci 19:119-131.

Marc RE, Liu W (2000) Fundamental GABAergic amacrine cell circuitries in the retina: nested feedback, concatenated inhibition, and axosomatic synapses. J Comp Neurol 425:560-582.
Masland RH, Raviola E (2000) Confronting complexity: strategies for understanding the microcircuitry of the retina. Annu Rev Neurosci 23:249-284.

Massey SC, Mills SL (1996) A calbindin-immunoreactive cone bipolar cell type in the rabbit retina. J Comp Neurol 366:15-33.

Massey SC, Mills SL (1999) Antibody to calretinin stains AII amacrine cells in the rabbit retina: double-label and confocal analyses. J Comp Neurol 411:3-18.

Matsui K, Hasegawa J, Tachibana M (2001) Modulation of excitatory synaptic transmission by $\mathrm{GABA}(\mathrm{C})$ receptor-mediated feedback in the mouse inner retina. J Neurophysiol 86:2285-2298.

Pan ZH (2001) Voltage-activated $\mathrm{Ca}^{2+}$ channels and ionotropic GABA receptors localized at axon terminals of mammalian retinal bipolar cells. Vis Neurosci 18:279-288.

Protti DA, Llano I (1998) Calcium currents and calcium signaling in rod bipolar cells of rat retinal slices. J Neurosci 18:3715-3724.

Sandell JH, Masland RH (1986) A system of indoleamine-accumulating neurons in the rabbit retina. J Neurosci 6:3331-3347.

Shields CR, Tran MN, Wong RO, Lukasiewicz PD (2000) Distinct ionotropic GABA receptors mediate presynaptic and postsynaptic inhibition in retinal bipolar cells. J Neurosci 20:2673-2682.

Soucy E, Wang Y, Nirenberg S, Nathans J, Meister M (1998) A novel signaling pathway from rod photoreceptors to ganglion cells in mammalian retina. Neuron 21:481-493.

Sterling P (1998) Retina. In: The synaptic organization of the brain, Ed 4 (Shepherd G, ed), pp 205-253. New York: Oxford UP.

Strettoi E, Dacheux RF, Raviola E (1990) Synaptic connections of rod bipolar cells in the inner plexiform layer of the rabbit retina. J Comp Neurol 295:449-466.

Strettoi E, Raviola E, Dacheux RF (1992) Synaptic connections of the narrow-field, bistratified rod amacrine cell (AII) in the rabbit retina. J Comp Neurol 325:152-168.

Taylor WR (1999) TTX attenuates surround inhibition in rabbit retinal ganglion cells. Vis Neurosci 16:285-290.

Vaney DI (1986) Morphological identification of serotonin-accumulating neurons in the living retina. Science 233:444-446.

Vaney DI (1994) Pattern of neuronal coupling in the retina. Prog Retin Eye Res 13:301-355.

Volgyi B, Xin D, Bloomfield SA (2002) Feedback inhibition in the inner plexiform layer underlies the surround-mediated responses of AII amacrine cells in the mammalian retina. J Physiol (Lond) 539:603-614.

Wässle H, Grunert U, Chun MH, Boycott BB (1995) The rod pathway of the macaque monkey retina: identification of AII-amacrine cells with antibodies against calretinin. J Comp Neurol 361:537-551.

Xin D, Bloomfield SA (1997) Tracer coupling pattern of amacrine and ganglion cells in the rabbit retina. J Comp Neurol 383:512-528.

Yang H, Standifer KM, Sherry DM (2002) Synaptic protein expression by regenerating adult photoreceptors. J Comp Neurol 443:275-288.

Young HM, Vaney DI (1991) Rod-signal interneurons in the rabbit retina: 1. Rod bipolar cells. J Comp Neurol 310:139-153. 